\title{
The occurrence of glucosinolates during the flowering and maturation of oilseed rape (Brassica napus $L$.)
}

\author{
LUCYNA DROZDOWSKA and JANINA ROGOZINSKA
}

Laboratory of Plant Physiology, Institute of Agriculture, Technical-Agricultural Academy, Bernardyńska 6, 85-029 Bydgoszcz, Poland

(Received: April 21, 1980)

\begin{abstract}
It was found that in the vegetative organs of rape, glucosinolates are present in insignificant amounts and their content decreases toward development. Higher amounts were found in flower buds; in the course of seed formation, continuous accumulation of glucosinolates proceeds up to the stage of technical maturity. Among the glucosinolates, progoitrin predominated during all developmental stages.
\end{abstract}

\section{INTRODUCTION}

Glucosinolate content in rape seeds has been the subject of several recent studies but information on the glucosinolate content in the vegetative organs is lacking. This paper reports the content of glucosinolates in the vegetative and generative organs of rape in the course of flowering and maturation.

\section{MATERIAL AND METHODS}

The experiments were conducted on winter rape (Brassica napus L. var. oleifera, cv. 'Skrzeszowicki') which is characterized by a high glucosinolate content. The following isothiocyanates were determined: 3-butenyl (ITC-B) and 4-pentenyl (ITC-P) isothiocyanates and L-5-vinyl-2-oxazolidinethione (VOT). These are the breakdown products of three glucosinolates, commonly present in rape: gluconapin, glucobrassicanapin and progoitrin ( $\mathrm{K} \mathrm{j}$ a e r, 1960; J o s e f s s o n, 1967; K r z y m a n s ki, 1970). The hydrolysis is accomplished by the enzyme myrosinase, yielding sulphate, glucose and isothiocyanates or nitriles ( $\mathrm{J}$ o s e f s s o $\mathrm{n}, 1970 \mathrm{~b}$ ). The volatile isothiocyanates were estimated 
by gas chromatography and the nonvolatile VOT spectrophotometrically. The methods of Youngs and Wetter as well as of Josefsson and Appelqvist in the modification of $\mathrm{B} \mathrm{y} \mathrm{c} \mathrm{z} \mathrm{y} \mathrm{ń} \mathrm{s} \mathrm{k} \mathrm{a} \mathrm{(1971)} \mathrm{were} \mathrm{used.}$

\section{RESULTS AND DISCUSSION}

The glucosinolate content of rape is related to the developmental stages and is affected by variety as well as environment, such as fertilizers, temperature, light (J o s e f s s o n, 1970a; D r o z d o w s k a and R o g o z i n s k a, 1981.). Isothiocyanates, products of glucosinolate hydrolysis, as well as isothiocyanate secondary products, may be toxic to animals.

The results shown in Table 1 illustrate the glucosinolate content in the vegetative organs of rape in the course of flowering up to the stage of technical maturation. In the leaves, stems and roots those compounds are present in insignificant amounts. Among the glucosinolates analysed, VOT, a product of progoitrin hydrolysis is predominant. The largest amounts of this compound were detected in the leaves at the time preceding flowering and after the period of flowering in the stems and roots. Glucobrassicanapin, determined after its hydrolysis to ITC-P, was detected in lesser amounts. In the course of plant maturation, the amount of glucosinolates in the leaves and stems decreased. In the roots, the largest quantities were detected after flowering. ITC-B, derived from the breakdown of gluconapin, was present only in trace amounts and sometimes was absent. This concerns both the period preceding flowering as well as the period of flowering and technical maturity.

Thus, among the organs analysed, the largest content of VOT and isothiocyanates was found in the leaves in the time preceding flowering as well as in the course of flowering. On the other hand, after flowering, the largest amounts of glucosinolates were present in the roots. Thus, the glucosinolate content in the vegetative organs is variable, depending on the developmental stage of the plant. There is a continuous aecrease of these compounds, and in the stage of technical maturity only trace amounts of glucosinolates were detected in the roots. This may indicate that the vegetative organs are depleted of the glucosinolates due to the transport of the latter to the developing seeds.

Somewhat differently runs the glucosinolate metabolism in the developing generative organs. Table 2 shows that in the flower buds ITC-P was present in the largest amounts followed by VOT and ITC-B. The contents of these glucosinolates gradually increased and the quantitative proportions between them changed. In the time preceding flowering VOT predominated and ITC-B was present in the smallest quantities.

Detailed estimates performed during flowering indicate that, in the pistils, the glucosinolates are present in the largest quantities, followed by the stamens. In smaller amounts some of them were detected in the petals and sepals (Table 3). 
Ta b le 1

Glucosinolate content $(\mathrm{mg} / \mathrm{g}$ fr. $w \mathrm{t})$ in vegetative organs of rape depending on developmental stages

\begin{tabular}{|c|c|c|c|c|c|c|c|c|c|}
\hline \multirow{2}{*}{$\begin{array}{l}\text { Time at which the } \\
\text { material was taken } \\
\text { for analysis }\end{array}$} & \multicolumn{3}{|c|}{ Leaves } & \multicolumn{3}{|c|}{ Stems } & \multicolumn{3}{|c|}{ Roots } \\
\hline & ITC-B & ITC-P & VOT & ITC-B & ITC-P & VOT & ITC-B & ITC-P & VOT \\
\hline \multicolumn{10}{|l|}{ Ca 1 week before } \\
\hline flowering & 0.006 & 0.028 & 0.148 & 0.0 & 0.009 & 0.013 & 0.0 & 0.004 & 0.0 \\
\hline Flowering & 0.006 & 0.017 & 0.016 & 0.0 & 0.010 & 0.012 & 0.0 & 0.013 & 0.016 \\
\hline \multicolumn{10}{|l|}{$\mathrm{Ca} 1$ week after } \\
\hline flowering & 0.006 & 0.016 & 0.007 & 0.001 & 0.004 & 0.028 & 0.006 & 0.030 & 0.102 \\
\hline Technical maturity & 0.0 & 0.0 & 0.0 & 0.001 & 0.0 & 0.0 & 0.01 & 0.002 & 0.016 \\
\hline
\end{tabular}

T a b l e 2

Glucosinolate content in developing flower buds

\begin{tabular}{lrrrr}
\hline $\begin{array}{c}\text { Time at which the material } \\
\text { was taken for analysis }\end{array}$ & Date & \multicolumn{3}{c}{$\mathrm{mg} / \mathrm{g}$ fresh weight } \\
\hline ITC-B & ITC-P & VOT \\
The appearance of flower buds & 4.05 .1976 & 0.016 & 0.104 & 0.077 \\
Ca 1 week after the appearance & 11.05 .1976 & 0.020 & 0.090 & 0.072 \\
$\quad$ of flower buds & 2.05 .1977 & 0.036 & 0.156 & 0.160 \\
Ca 2 weeks after the appearance & 18.05 .1976 & 0.030 & 0.114 & 0.067 \\
$\quad$ of flower buds & 9.05 .1977 & 0.030 & 0.156 & 0.142 \\
Ca 1 week before & 25.05 .1976 & 0.060 & 0.126 & 0.254 \\
$\quad$ flowering & 16.05 .1977 & 0.060 & 0.148 & 0.331 \\
Full blossom & 1.06 .1976 & 0.055 & 0.099 & 0.211 \\
& 23.05 .1977 & 0.036 & 0.096 & 0.156 \\
\hline
\end{tabular}


T a ble 3

Glucosinolate content in flower elements

\begin{tabular}{llll}
\hline \multirow{2}{*}{ Flower parts } & \multicolumn{3}{c}{$\mathrm{mg} / \mathrm{g}$ fresh weight } \\
\cline { 2 - 4 } & ITC-B & ITC-P & VOT \\
\hline Pistils & 0.060 & 0.140 & 0.160 \\
Stamens & 0.030 & 0.100 & 0.120 \\
Petals & 0.012 & 0.024 & 0.0 \\
Sepals & 0.0 & 0.0 & 0.106 \\
\hline
\end{tabular}

Seed maturation and reserve material accumulation is accompanied also by the accumulation of the secondary metabolites investigated by $\mathrm{B} \mathrm{y} \mathrm{c} \mathrm{z}$ y ń$\mathrm{s} \mathrm{k}$ a et al. (1970). As shown in Table 4, there is a continuous increase in glucosinolates, the accumulation of which proceeds progressively during seed development and ripening. In immature seeds (ca 6 days old) only VOT was detected among the glucosinolates tested. Isothiocyanate 3-butenyl and 4pentenyl appeared in the seeds in the course of their ripening and were detected in 13-day-old seeds. The continuous accumulation of ITC-P and VOT lasted until technical maturity and that of ITC-B up to the time of half-technical maturity (Table 4). In the seeds, similarly as in the case of the vegetative organs, VOT

T a b l e 4

Glucosinolate content during seed ripening

\begin{tabular}{cllll}
\hline \multirow{2}{*}{$\begin{array}{c}\text { Days after the } \\
\text { end of flowering }\end{array}$} & Maturity stages & \multicolumn{3}{c}{$\mathrm{mg} / \mathrm{g}$ fresh weight } \\
\cline { 3 - 5 } & & ITC-B & ITC-P & VOT \\
\hline 6 & green & 0.0 & 0.0 & 0.760 \\
13 & green & 0.130 & 0.040 & 0.220 \\
20 & green & 0.724 & 0.220 & 1.128 \\
26 & half-technical & 0.732 & 0.232 & 1.488 \\
31 & half-technical & 0.600 & 0.240 & 1.752 \\
41 & technical & 0.648 & 0.300 & 1.780 \\
\hline
\end{tabular}

predominated among the glucosinolates during all stages of seed development. The results are in agreement with earlier investigations reported by $\mathrm{K}$ o $\mathrm{n} \mathrm{d} \mathrm{r} \mathrm{a}$ and D o w n e y (1969) and B y c z y ń s k a et al. (1970) using summer rape and an other variety of winter rape.

As demonstrated by the experiments, the occurrence of glucosinolates depends both on the developmental stage of the plant as well as on the organ. In the vegetative stage of the plant, these compounds occur only in insignificant amounts. The transition of the plants from the vegetative to the generative stage is 
accompanied by a temporarily increased glucosinolate content, may be due to enhanced synthesis and transport to the developing generative organs. This is supported by B y c z y ń s k a et al. (1970) who have shown that seeds threshed from the plants and dried in shed have a higher glucosinolate content than seeds threshed just after harvest.

\section{Acknowledgements}

We are indebted to Professor J. Krzymański and Dr B. Byczyńska for the glucosinolate analyses performed in their laboratory at the Institute of Plant Breeding and Acclimatization, Poznan.

\section{REFERENCES}

B y c z y ń s k a B., K r z y m a ń s k i J., W i ą z e c k a K., 1970. Zawartość izotiocyjanianów i oksazolidyntionów w nasionach rzepaku ozimego w czasie ich formowania i dojrzewania. Hod. Rośl. Aklim. 14: 547-551.

B y c z y ń s k a B., 1971. Oznaczanie izotiocyjanianów i oksazolidyntionów w nasionach rzepaku. Biul. Inst. Hod. Rośl. 5: 57-61.

D r ozd ow sk a L., R o g o z i ń s k a J. H., 1981. Wplyw światła i siarki na metabolizm glukozynolanów w siewkach rzepaku. Biul. Inst. Hod. Rośl. 148: 135-141.

J o s e is s o n E., 1967. Distribution of thioglucosides in different parts of Brassica plants. Phytochemistry, 6: 1617-1627.

J o s e f s s o n E., 1970a. Pattern, content and biosynthesis of glucosinolates in some cultivated Cruciferae. Swedish Seed Association, Svalöf, 1-42.

J o s e f s s o n E., 1970b. Glucosinolate content and amino acid composition of rapeseed (Brassica napus) meal as affected by sulphur and nitrogen nutrition. J. Sci. Fd Agric. 21: 98-103.

$\mathrm{K}$ j a e r A., 1960. Naturally derived isothiocyanates and their parent glucosides. Fortschr. Chem. Org. Naturstoffe, 18: 123-176.

K o n d r a Z.P., D o w n e y R. K., 1969. Glucosinolate content of developing Brassica napus and Brassica campestris seed. Can. J. Plant Sci. 5: 623-624.

$\mathrm{K}$ r $\mathrm{z}$ y m a ń s k i J., 1970. Genetyczne możliwości ulepszania skladu chemicznego nasion rzepaku ozimego. Hod. Rośl. Aklim. 14: 95-133.

\section{Występowanie glikozynolanów w czasie kwitnienia i dojrzewania rzepaku (Brassica napus L.)}

\section{Streszczenie}

Stwierdzono, że w organach wegetatywnych rzepaku glikozynolany występują w nieznacznych ilościach i zawartość ich obniża się wraz z rozwojem roślin. Większe ilości obecne są w pąkach kwiatowych; w czasie tworzenia nasion następuje nagromadzenie glikozynolanów trwające do stanu dojrzałości technicznej. Wśród glikozynolanów, we wszystkich stadiach rozwojowych przeważała progoitryna. 